\title{
Validation of a definition of excessive postoperative bleeding in infants undergoing cardiac surgery with cardiopulmonary bypass
}

\author{
Rachel S. Bercovitz, MD, MS, ${ }^{\mathrm{a}, \mathrm{b}, \mathrm{d}}$ Allison C. Shewmake, MD, ${ }^{\mathrm{c}}$ Debra K. Newman, PhD,,${ }^{\mathrm{d} e}$ \\ Robert A. Niebler, MD ${ }^{\text {f,g }}$ John P. Scott, MD, ${ }^{\text {h,i }}$ Eckehard Stuth, MD, ${ }^{\mathrm{g}, \mathrm{h}}$ Pippa M. Simpson, PhD, ${ }^{\mathrm{i}}$ \\ Ke Yan, $\mathrm{PhD},{ }^{\mathrm{j}}$ and Ronald K. Woods, MD, $\mathrm{PhD}^{\mathrm{g}, \mathrm{k}}$
}

\section{ABSTRACT}

Objective: To derive and validate an objective definition of postoperative bleeding in neonates and infants undergoing cardiac surgery with cardiopulmonary bypass.

\begin{abstract}
Methods: Using a retrospective cohort of 124 infants and neonates, we included published bleeding definitions and cumulative chest tube output over different postoperative periods (eg, 2, 12, or 24 hours after intensive care unit admission) in a classification and regression tree model to determine chest tube output volumes that were associated with red blood cell transfusions and surgical reexploration for bleeding in the first 24 hours after intensive care unit admission. After the definition of excessive bleeding was determined, it was validated via a prospective cohort of 77 infants and neonates.
\end{abstract}

Results: Excessive bleeding was defined as $\geq 7 \mathrm{~mL} / \mathrm{kg} / \mathrm{h}$ for $\geq 2$ consecutive hours in the first 12 postoperative hours and/or $\geq 84 \mathrm{~mL} / \mathrm{kg}$ total for the first 24 postoperative hours and/or surgical re-exploration for bleeding or cardiac tamponade physiology in the first 24 postoperative hours. Excessive bleeding was associated with longer length of hospital stay, increased 30-day readmission rate, and increased transfusions in the postoperative period.

Conclusions: The proposed standard definition of excessive bleeding is based on readily obtained objective data and relates to important early clinical outcomes. Application and validation by other institutions will help determine the extent to which our specialty should consider this definition for both clinical investigation and quality improvement initiatives. (J Thorac Cardiovasc Surg $2018 ; 155: 2112-24)$

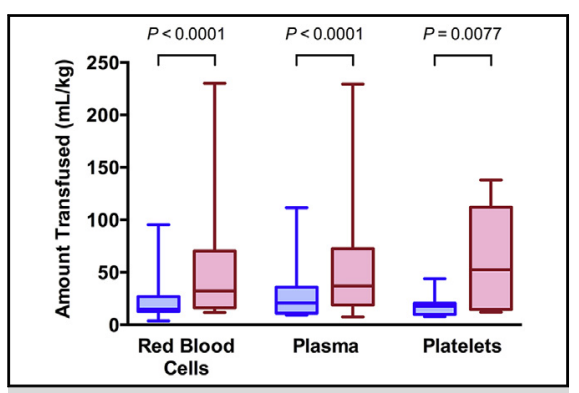

Total transfusion volume is greater in bleeders (red) than nonbleeders (blue) in the first 7 days.

\section{Central Message}

We derived and validated a definition of postoperative bleeding that can be applied to neonatal and infant cardiac surgery patients in both the research and practice improvement settings.

\section{Perspective}

Excessive postoperative bleeding in neonates and infants undergoing surgical repair of congenital heart disease is a significant problem. Absence of a standardized objective definition of bleeding is a barrier to improving bleeding-related outcomes. The use of our definition has the potential to improve clinical research and patient care with respect to diagnosis, prevention, and treatment of bleeding.

See Editorial Commentary page 2125.
Excessive postoperative bleeding after surgical repair of congenital heart disease (CHD) requiring cardiopulmonary bypass $(\mathrm{CPB})$ is associated with significant morbidity and

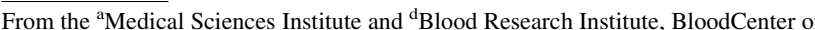
Wisconsin, Milwaukee, Wis; ${ }^{\mathrm{b}}$ Division of Hematology and Oncology, Departments of Pathology, Pediatrics, ${ }^{\mathrm{c}}$ School of Medicine, ${ }^{\mathrm{e}}$ Department of Pharmacology \& Toxicology, ${ }^{\mathrm{f}}$ Division of Pediatric Critical Care, Department of Pediatrics, ${ }^{\mathrm{h}}$ Division of Pediatric Anesthesia, Department of Anesthesia, ${ }^{\mathrm{i}}$ Division of Quantitative Health Sciences of Wisconsin, Department of Pediatrics, ${ }^{j}$ Department of Biostatistics, and ${ }^{\mathrm{k}}$ Division of Pediatric Cardiothoracic Surgery, Department of Surgery, Medical College of Wisconsin, Milwaukee, Wis; and ${ }^{\mathrm{g}} \mathrm{Herma}$ Heart Center, Children's Hospital of Wisconsin, Milwaukee, Wis.

This study was funded in part by HTRS/Novo Nordisk 2015 Mentored Research Award in Hemophilia or Rare Bleeding Disorders from the Hemostasis and Throm- mortality. ${ }^{1-4}$ However, there is no standard definition of postoperative bleeding that is universally applied in pediatric cardiac surgery patients. One consequence of 

Abbreviations and Acronyms
CART $=$ classification and regression tree
CHD $=$ congenital heart disease
CI = confidence interval
$\mathrm{CICU}=$ cardiac intensive care unit
$\mathrm{CPB}=$ cardiopulmonary bypass
$\mathrm{CTO}=$ chest tube output
$\mathrm{EBV}=$ estimated blood volume
$\mathrm{RBC}=$ red blood cell

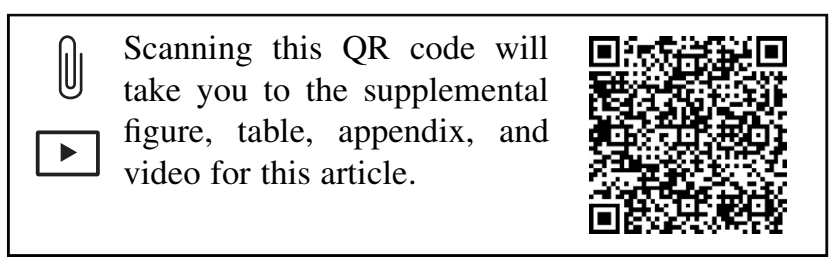

having varying definitions of bleeding is a wide range of bleeding incidence $(0 \%-42 \%)$ in studies of these patients. ${ }^{3-20}$ As with other outcomes, ${ }^{21}$ intercenter variability in patient population and clinical practices likely contributes to a true difference in bleeding incidence; however, a study that uses chest tube output (CTO) greater than $20 \%$ of estimated blood volume (EBV) in 24 hours $^{19}$ is likely to have more bleeders than a study that uses $20 \%$ EBV in the first 2 postoperative hours. ${ }^{11}$

Frequently, postoperative bleeding is defined by using CTO, starting from the time of admission to the cardiac intensive care unit (CICU); many studies have a specific threshold above which is considered excessive (eg, $\geq 10 \mathrm{~mL} / \mathrm{kg}$ in the first 4 postoperative hours), ${ }^{5-7,10,11,16,17,22}$ some report CTO as a continuous outcome, ${ }^{1,23,24}$ and others define bleeding as patients in the top 25th percentile for CTO., ${ }^{3,4,25}$ However, many of these definitions lack a rationale for the specific CTO threshold values that separate patients with and without bleeding. A validated definition of excessive postoperative bleeding that is associated with outcomes such as transfusions or surgical re-exploration could facilitate multi-institutional trials designed to address bleeding prevention and management in these complicated patients.

Children $<12$ months old comprise $56 \%$ of the patients who undergo surgical correction of CHD annually in the United States and account for $83 \%$ of the mortality. ${ }^{26} \mathrm{Neo}-$ nates and young infants are at the greatest risk of perioperative bleeding due to immature coagulation systems and exaggerated hemodilution due to the disproportionate ratio of CPB circuit volume to patient blood volume. ${ }^{27,28} \mathrm{~A}$ definition of bleeding for this specific group of patients that is objective and clinically relevant would be an asset to our specialty.
The goal of this study was to derive objective definitions of excessive postoperative CTO and bleeding in neonates and infants undergoing cardiac surgery with CPB. First, we reviewed the literature to identify appropriate articles on the subject of bleeding definitions specific to this patient population. Next, we applied these definitions as well as other iterations of cumulative CTO to a retrospective cohort to determine association with re-exploration for bleeding or transfusion of red blood cells (RBCs) in the first 24 hours after admission to the CICU, which are 2 of the most common sequelae of postoperative bleeding. ${ }^{2} \mathrm{We}$ then validated the derived definition in a prospective cohort of patients. Based on this analysis, we offer a new standardized definition of postoperative bleeding that may be appropriate for use in neonatal and infant pediatric cardiac surgery patients in both the research and practice improvement settings.

\section{METHODS}

\section{Literature Review}

To find definitions of bleeding used in studies of pediatric patients undergoing surgery with $\mathrm{CPB}$, the following PubMed search was performed: $\left(\left(\left(\left(\left(\left(\right.\right.\right.\right.\right.\right.$ bleed $\left.\left.^{*}\right)\right)$ OR "excessive bleeding") OR "bled excessively") OR hemorrhage)) AND surgery) AND card*) AND "cardiopulmonary bypass." Search results were limited to articles in English in which the study population was children undergoing surgical repair of $\mathrm{CHD}$ with $\mathrm{CPB}$. Articles were screened for relevance using title, and articles in which excessive postoperative bleeding was either a predictor variable or an outcome of interest were identified by review of the abstracts. Additional articles were found by manually searching the reference lists of primary articles and reviews. Only articles that provided a detailed definition of excessive bleeding in the methods section were selected for inclusion in this manuscript. Studies that compared median or mean CTO between 2 or more groups of patients were not included.

\section{Determination and Validation of Bleeding Definition}

All studies that used retrospective and prospective patient data were approved by the local institutional review board. IRB approval information: retrospective review, IRB of record: Children's Hospital of Wisconsin, approval date: June 18, 2014, IRB \#: 14/88; prospective study (children $\leq 30$ days old), IRB of record: Children's Hospital of Wisconsin, approval date: March 18, 2014, IRB \#: 14/31; and prospective study (children $\geq 31$ days old), IRB of record: Children's Hospital of Wisconsin, approval date: September 15, 2015, IRB \#: 15/112.

Retrospective review (test cohort). A retrospective review of 130 neonates and infants $<6$ months old who underwent congenital heart surgery requiring $\mathrm{CPB}$ at Children's Hospital of Wisconsin from June 2012 to May 2014 was performed. Six patients were excluded because of placement on extracorporeal membrane oxygenation postoperatively. For subjects having more than 1 cardiac surgery during this time period, only the first operation was included.

Prospective studies (validation cohort). Two observational studies were performed of neonates and infants undergoing cardiac surgery at Children's Hospital of Wisconsin from June 2014 to May 2017. One study included neonates and the other included infants 31 to 365 days old at the time of surgery. A total of 76 subjects (44 neonates, 58\%) were enrolled in these studies. Exclusion criteria were weight $<2.5 \mathrm{~kg}$ and preoperative extracorporeal membrane oxygenation. 


\section{Standard Patient Management (Test and Validation Cohorts)}

After induction of general anesthesia, patients were cannulated for CPB. The CPB circuit was primed with either whole blood ( $<5$ days old) or equal amounts fresh RBCs and frozen plasma. Whole blood was preferred and used when available. Tranexamic acid was routinely administered (10$20 \mathrm{mg} / \mathrm{kg}$ ) before incision. Most patients received both platelet and cryoprecipitate transfusions when transitioning off of the $\mathrm{CPB}$ circuit, although in cases in which patients had an on-CPB platelets $>100,000 / \mu \mathrm{L}$, the platelet transfusion was deferred based on the surgeon's preference. Further transfusions were administered as needed and at the discretion of the anesthesiologist and surgeon. Recalcitrant bleeding without a surgical source not responsive to blood product administration was treated with recombinant activated factor VII in dose increments of $90 \mu \mathrm{g} / \mathrm{kg}$. All efforts were made to achieve full hemostasis before transfer to the CICU.

\section{Statistical Analysis}

Data were summarized with medians and range. Univariate tests, including Wilcoxon rank sum tests, or Fisher exact test for categorical variables, were used to investigate relevant predictors of the outcomes of interest with a significance level of .05. For binary categorical variables, risk ratio is reported with $95 \%$ confidence intervals (CIs).

To determine a threshold of excessive CTO, the primary outcomes of interest were transfusion of RBCs or surgical re-exploration for bleeding in the first $24 \mathrm{CICU}$ hours. Classification and regression trees (CART) were used to determine the amount (absolute and average, $\mathrm{mL} / \mathrm{kg}$ ) and duration (hours) of CTO that best predicted a positive outcome. Included in this CART analysis were all published definitions, cumulative CTO over different time spans $(2,4,6,12$, and 24 hours postoperatively), and number of hours with CTO above various volumes $(3,4,5,6,7$, and $8 \mathrm{~mL} / \mathrm{kg} / \mathrm{h}$ ).

CART analysis ${ }^{29,30}$ consists of 4 components: (1) an outcome variable (in this case, RBC transfusion or surgical re-exploration); (2) predictor variables (in this case, varying CTO amounts over varying time periods); (3) a test cohort (patients in the retrospective study); and (4) a validation cohort (patients in the prospective studies). An advantage of CART analysis over typical multiple variable regression models is that it can handle a large number of interrelated variables and goes through a series of yes/no questions to find important relationships (or nodes). ${ }^{30}$ A stepwise approach of removing variables similar to nodes as they were established was used to achieve the a priori goal of having a definition that included thresholds for both early/acute high CTO volumes as well as sustained CTO over a clinically relevant time period. A complete list of variables as well as the CART analysis is in the Appendix E1.

For time-to-discharge analysis, in-hospital mortality was treated as a competing outcome and separate analyses were performed on patients who underwent a Norwood procedure because some subjects remained hospitalized until the second stage surgery, which would have artificially prolonged length of stay. Probabilities of interest are the cumulative incidence functions for either event type, in-hospital mortality, or hospital discharge. These functions estimate the probability of experiencing a specific event by a given time while allowing for the possibility of other events to occur. ${ }^{31}$ To detect a $40 \%$ difference in incidence of the outcome of interest between patients with and without bleeding, assuming an incidence of bleeding $>20 \%$, we needed a minimum of 120 patients in the test cohort. Statistical analyses were performed with SAS Studio 3.5 (SAS, Cary, NC) and Prism 6.0h (GraphPad, La Jolla, Calif), and R (https://r-project.org/) was used for CART analysis.

\section{RESULTS}

\section{Literature Review}

Our original search yielded 593 articles, and an additional 15 articles were identified after a review of the references (Figure E1). Based on our selection criteria for methodologic description of excessive bleeding, a total of 21 articles were included: 8 prospective studies, 11 retrospective studies, 1 review article, and 1 textbook chapter (Table 1). ${ }^{3-12,14-20,22,32-34}$ Three definitions were used by more than 1 study, resulting in 17 unique definitions.

\section{Retrospective Review (Test Cohort)}

Data from 124 infants $\leq 180$ days old, including 68 $(55 \%)$ neonates, undergoing cardiac surgical procedures requiring CPB were included in our final analysis. Table 2 summarizes the demographic and clinical patient data.

\section{Literature Review Results Applied to Test Cohort}

Applying the published definitions to the retrospective cohort revealed that $90 \%$ (112) of these patients would have met the criteria for excessive bleeding based on 1 or more of these definitions. Of the 17 definitions, 1 was excluded from analysis because it defined bleeders as patients who had undergone re-exploration for bleeding but did not specify the criteria that prompted re-exploration. ${ }^{8}$ Of the 16 remaining definitions, 11 were associated with an increased risk of either RBC transfusion or re-exploration for bleeding in the first 24 postoperative hours (data not shown).

\section{Determination of Excessive CTO}

Although many of the published definitions were associated with a significantly greater risk of the outcomes of interest, none provided a rationale for the specific threshold chosen. Therefore, we included in the CART analysis not only the published definitions but also additional permutations of CTO in terms of volume, duration, and time period other than those presented in the published definitions. Thirty-nine patients $(31.5 \%)$ had the outcomes of interest in the first postoperative 24 hours (26 patients received at least $1 \mathrm{RBC}$ transfusion, 4 underwent re-exploration for bleeding, and 9 had both outcomes).

The first node of the CART analysis was CTO $\geq 84 \mathrm{~mL} /$ $\mathrm{kg}$ for 24 hours, risk ratio: 2.7 (95\% CI, 1.7-4.3), $P=.0013$ (Figure 1). Because this number represented cumulative CTO, other variables of cumulative output were removed from the model for subsequent nodes (eg, 6- and 12-hour CTO). Of the measures that represented short-term, high CTO, none reached statistical significance as a second node in the model. However, CTO of $\geq 7 \mathrm{~mL} / \mathrm{kg} / \mathrm{h}$ for $\geq 2$ consecutive hours in the first 12 hours was associated with the greatest risk ratio of $\mathrm{RBC}$ transfusion or reexploration compared with similar variables (eg, $\geq 6 \mathrm{~mL} /$ $\mathrm{kg} / \mathrm{h}$ for $\geq 2$ hours or $\geq 5 \mathrm{~mL} / \mathrm{kg} / \mathrm{h} \geq 3$ hours), risk ratio: 2.3 (1.2-4.5) $P=.0640$. Patients who met one or both of the CTO criteria had a 2.8-fold greater risk of RBC transfusion or re-exploration than patients with less CTO $(95 \% \mathrm{CI}$, $1.7-4.4), P=.0002$. This increase in risk was slightly greater compared with the published definitions whose risk ratios ranged from 1.7 to 2.6 . 
TABLE 1. Articles identified through literature review

\begin{tabular}{|c|c|c|c|c|c|c|}
\hline Study & Year & Type & Age & $\mathbf{n}$ & Definition & Incidence, $\%$ \\
\hline Pekelharing and colleagues ${ }^{14}$ & 2014 & Prospective & $<18 \mathrm{y}$ & 107 & $\geq 5 \mathrm{~mL} / \mathrm{kg} / \mathrm{h}$ in first $4 \mathrm{~h}$ & 21.4 \\
\hline Moganasundram and colleagues ${ }^{9}$ & 2010 & Prospective & $<5 \mathrm{y}$ & 50 & $>10 \mathrm{~mL} / \mathrm{kg}$ in first $4 \mathrm{~h}$ & 38 \\
\hline Faraoni and colleagues ${ }^{32}$ & 2015 & Retrospective & $\leq 16 \mathrm{y}$ & 150 & $>10 \% \mathrm{EBV}$ in first $6 \mathrm{~h}$ & 23 \\
\hline Savan and colleagues ${ }^{20}$ & 2014 & Retrospective & $\leq 16$ y & 182 & $>10 \% \mathrm{EBV}$ in first $6 \mathrm{~h}$ & 28.9 \\
\hline Timpa and colleagues ${ }^{18}$ & 2016 & Prospective & $<18 \mathrm{y}$ & 161 & $>10 \mathrm{~mL} / \mathrm{kg}$ in the first $\mathrm{CICU}$ hour & 26 \\
\hline Niebler and colleagues ${ }^{10}$ & 2012 & Prospective & $<18$ y & 60 & $>6 \mathrm{~mL} / \mathrm{kg} / \mathrm{h}$ for $\geq 2$ consecutive hours in $6 \mathrm{~h}$ & 31.7 \\
\hline Niles and colleagues ${ }^{12}$ & 2008 & Retrospective & $<18 \mathrm{y}$ & 328 & $>4 \mathrm{~mL} / \mathrm{kg} / \mathrm{h}$ for $\geq 2$ consecutive hours in $7 \mathrm{~h}$ & NA \\
\hline Tobias and colleagues $^{22}$ & 2004 & Retrospective & $<18 \mathrm{y}$ & 17 & $\geq 12 \mathrm{~mL} / \mathrm{kg}$ for the first 3 postoperative hours & NA \\
\hline Razon and colleagues ${ }^{16}$ & 2005 & Prospective & $\leq 19 \mathrm{y}$ & 5 & $\begin{array}{l}>8 \mathrm{~mL} / \mathrm{kg} \text { for any } 1 \mathrm{~h} \text { or } \\
>4 \mathrm{~mL} / \mathrm{kg} / \mathrm{h} \text { for } \geq 3 \text { consecutive hours }\end{array}$ & NA \\
\hline Agarwal and colleagues ${ }^{5}$ & 2015 & Retrospective & $<18$ y & 253 & $\begin{array}{l}>10 \mathrm{~mL} / \mathrm{kg} \text { in the first hour or } \\
>5 \mathrm{~mL} / \mathrm{kg} \text { for } 3 \text { consecutive hours in } 12 \mathrm{~h}\end{array}$ & 42 \\
\hline Guay and Rivard ${ }^{33}$ & 1996 & Review & NA & NA & $\begin{array}{l}>10 \% \mathrm{EBV} \text { in any } 1 \text { hour or } \\
>5 \% \mathrm{EBV} \text { for } 3 \text { consecutive hours in } 24 \text { hours }\end{array}$ & NA \\
\hline Oliver $^{34}$ & 2005 & Textbook & $<18$ y & NA & $\begin{array}{l}>10 \% \mathrm{EBV} \text { in any } 1 \text { hour or } \\
>5 \% \mathrm{EBV} \text { for } 3 \text { consecutive hours in } 24 \text { hours }\end{array}$ & NA \\
\hline Singh and colleagues ${ }^{17}$ & 2012 & Retrospective & $<15 \mathrm{y}$ & 20 & $\begin{array}{l}>10 \% \mathrm{EBV} \text { in any } 1 \text { hour or } \\
>5 \% \mathrm{EBV} \text { for } 3 \text { consecutive hours in } 24 \text { hours }\end{array}$ & NA \\
\hline Tirosh-Wagner and colleagues ${ }^{19}$ & 2011 & Prospective & $\leq 10 \mathrm{y}$ & 15 & $>20 \% \mathrm{EBV}$ in $24 \mathrm{~h}$ & NA \\
\hline Hoda and colleagues $^{7}$ & 2016 & Retrospective & $<18 \mathrm{y}$ & 82 & $>4 \mathrm{~mL} / \mathrm{kg} / \mathrm{h}$ average for $24 \mathrm{~h}$ & 0 \\
\hline Pychynska-Pokorska and colleagues ${ }^{15}$ & 2004 & Prospective & $<5 \mathrm{y}$ & 8 & $\begin{array}{l}\text { Children } \leq 5 \mathrm{~kg}: \geq 10 \mathrm{~mL} / \mathrm{kg} / \mathrm{h} \\
\text { Children } \geq 5 \mathrm{~kg}: \geq 2 \mathrm{~mL} / \mathrm{kg} / \mathrm{h}\end{array}$ & NA \\
\hline Williams and colleages ${ }^{11}$ & 1999 & Prospective & $<18$ y & 494 & $\begin{array}{l}\geq 20 \% \text { EBV in hours } 0-2 \text { or } \\
\geq 20 \% \text { EBV in hours } 2-6 \text { or } \\
\geq 30 \% \text { EBV in hours } 7-12\end{array}$ & 19 \\
\hline Brenner and colleagues $^{6}$ & 2015 & Retrospective & $<18 \mathrm{y}$ & 91 & $\begin{array}{l}\geq 20 \% \text { EBV in hours } 0-2 \text { or } \\
\geq 20 \% \text { EBV in hours } 2-6 \text { or } \\
\geq 30 \% \text { EBV in hours } 7-12\end{array}$ & 28.5 \\
\hline Guzzetta and colleagues $^{3}$ & 2015 & Retrospective & $\leq 30 \mathrm{~d}$ & 167 & Top 25th percentile for CTO in $24 \mathrm{~h}$ & 25 \\
\hline Wolf and colleagues ${ }^{4}$ & 2014 & Retrospective & $<1 \mathrm{y}$ & 1071 & Top 25th percentile for CTO in $12 \mathrm{~h}$ & 25 \\
\hline Kylasam and colleagues $^{8}$ & 2009 & Retrospective & $\leq 90 \mathrm{mo}$ & 25 & Required re-exploration for bleeding & 2.5 \\
\hline
\end{tabular}

$E B V$, Estimated blood volume $\left(<10 \mathrm{~kg}, 85 \mathrm{~mL} / \mathrm{kg} ; 10-20 \mathrm{~kg}, 80 \mathrm{~mL} / \mathrm{kg} ; 20-30 \mathrm{~kg}, 7 \mathrm{~mL} / \mathrm{kg} ;\right.$ and $\left.30-40 \mathrm{~kg}, 70 \mathrm{~mL} / \mathrm{kg}^{17,35}\right) ; C I C U$, cardiac intensive care unit; $N A$, not available; CTO, chest tube output.

\section{Bleeding Definition}

Based on this analysis, we define excessive CTO as $\geq 84 \mathrm{~mL} / \mathrm{kg}$ total for the first 24 postoperative hours ( $\geq 3.5 \mathrm{~mL} / \mathrm{kg} / \mathrm{h}$ average) and $/$ or $\geq 7 \mathrm{~mL} / \mathrm{kg} / \mathrm{h}$ for $\geq 2$ consecutive hours in the first 12 postoperative hours. In addition, to account for patients who may undergo re-exploration for bleeding before meeting the excessive CTO criteria or develop cardiac tamponade physiology secondary to bleeding rather than have excessive CTO, we propose a definition for excessive bleeding as patients who meet 1 or more of the following criteria:

(1) $\mathrm{CTO} \geq 7 \mathrm{~mL} / \mathrm{kg} / \mathrm{h}$ for $\geq 2$ consecutive hours in the first 12 postoperative hours;

(2) $\geq 84 \mathrm{~mL} / \mathrm{kg}$ total for the first 24 postoperative hours; or
(3) re-exploration for bleeding or cardiac tamponade physiology in the first 24 postoperative hours.

Thirty-one patients (25\%) met criteria for excessive postoperative bleeding (18 patients had excessive CTO, 1 was reexplored for bleeding, 5 were re-explored for tamponade in the first 24 postoperative hours, and 7 had both excessive CTO and were re-explored for bleeding). In univariate analyses, patients with excessive bleeding were younger, weighed less, spent more time on $\mathrm{CPB}$, and had a lower minimum body temperature intraoperatively (Table 3 ).

\section{Prospective Study (Validation Cohort)}

The 76 neonates and infants in the validation cohort were similar to those in the test cohort, as Table 2 shows. Of the 
TABLE 2. Patient demographics and clinical characteristics in the test (retrospective) cohort versus the validation (prospective) cohort

\begin{tabular}{|c|c|c|c|c|}
\hline Demographics, $n=200$ & Median (range) or $\mathbf{n}(\%)$ & $\begin{array}{c}\text { Test cohort } \\
n=124(\%)\end{array}$ & $\begin{array}{c}\text { Validation cohort } \\
\mathbf{n}=\mathbf{7 6}(\%)\end{array}$ & $P$ value \\
\hline Weight, kg & $3.8(2.2-13.3)$ & $3.8(2.2-8.7)$ & $3.8(2.6-13.3)$ & .3388 \\
\hline Age, d & $13.5(0-306)$ & $16(0-180)$ & $10(1-306)$ & .9619 \\
\hline Sex, female & $97(48.5)$ & $56(45.2)$ & $41(54)$ & .2461 \\
\hline \multicolumn{5}{|l|}{ STAT score } \\
\hline 1 & $24(12)$ & $15(12.1)$ & $9(11.8)$ & .1979 \\
\hline 2 & $42(21)$ & $22(17.7)$ & $20(26.3)$ & \\
\hline 3 & $32(16)$ & $20(16.1)$ & $12(15.8)$ & \\
\hline 4 & $54(27)$ & $39(31.5)$ & 15 (19.7) & \\
\hline 5 & $44(22)$ & $24(19.4)$ & $20(26.3)$ & \\
\hline NA & $4(2)$ & $4(3.2)$ & 0 & \\
\hline \multicolumn{5}{|l|}{ Preoperative labs } \\
\hline Hematocrit, \% & $41.2(24.2-60.5)$ & $41.3(24.2-55.7)$ & $40.8(31.4-60.5)$ & .8621 \\
\hline Platelet count, $\times 10_{3} / \mu \mathrm{L}$ & $328(56-755)$ & $349(104-755)$ & $317(56-595)$ & .0246 \\
\hline MPV, fL & $7.6(5.4-16.8)$ & $7.8(5.6-11.2)$ & $7.4(5.4-6.8)$ & .1877 \\
\hline High MPV, $\geq 9.5 \mathrm{fL}$ & $23(11.5)$ & $25(12.1)$ & $8(10.5)$ & .8221 \\
\hline \multicolumn{5}{|l|}{ Surgeon* } \\
\hline 1 & $50(25)$ & $31(25)$ & $19(25)$ & ND \\
\hline 2 & $62(31)$ & $51(41.1)$ & $11(15.5)$ & \\
\hline 3 & $77(38.5)$ & $42(33.9)$ & $35(46.1)$ & \\
\hline 4 & $11(5.5)$ & 0 & $11(14.5)$ & \\
\hline Time on CPB, min & $161(31-696)$ & $161(31-354)$ & $163(40-696)$ & .6268 \\
\hline Minimum temperature, ${ }^{\circ} \mathrm{C}$ & $28(14.1-37)$ & $28(16.7-37)$ & $29.7(14.1-35)$ & .0881 \\
\hline DHCA, yes & $73(36.5)$ & 47 (37.9) & $26(34.2)$ & .6513 \\
\hline Intraoperative rFVIIa & $14(7)$ & $11(8.9)$ & $3(4)$ & .2569 \\
\hline \multicolumn{5}{|l|}{ Prime } \\
\hline Whole blood & $99(49.5)$ & $72(58.1)$ & $27(35.5)$ & .0036 \\
\hline RBCs + plasma & $98(49)$ & $50(40.3)$ & $48(63.2)$ & \\
\hline Other & $3(1.5)$ & $2(1.6)$ & $1(1.3)$ & \\
\hline Delayed chest closure & $95(47.5)$ & $63(50.8)$ & $32(42.1)$ & .2464 \\
\hline \multicolumn{5}{|l|}{ Genetic syndrome } \\
\hline No & $150(75)$ & $100(80.7)$ & $50(65.8)$ & .0483 \\
\hline Trisomy 21 & $23(11.5)$ & $13(10.5)$ & $10(13.2)$ & \\
\hline 22q11 deletion syndrome & $10(5)$ & $4(3.2)$ & $6(7.9)$ & \\
\hline 16p duplication & $3(1.5)$ & 0 & $3(4)$ & \\
\hline Other & $14(7)$ & $7(5.7)$ & $7(9.2)$ & \\
\hline Single-ventricle physiology & $86(43)$ & $54(43.6)$ & $32(42.1)$ & .8837 \\
\hline Cyanotic heart disease (pre) & $152(76)$ & $88(71)$ & $64(84.2)$ & .0406 \\
\hline \multicolumn{5}{|l|}{ Procedure } \\
\hline ASD creation & $2(1)$ & $1(0.8)$ & $1(1.3)$ & \\
\hline ASD or VSD repair & $20(10)$ & $13(10.5)$ & $7(9.2)$ & \\
\hline AVC repair & $15(7.5)$ & $10(8.1)$ & $5(6.6)$ & \\
\hline Truncus arteriosus repair & $4(2)$ & $3(2.4)$ & $1(1.3)$ & \\
\hline TAPVC/R repair & $6(3)$ & $4(3.2)$ & $2(2.6)$ & \\
\hline TOF repair & $21(11.5)$ & $9(7.2)$ & $12(15.8)$ & \\
\hline Pulmonary atresia repair & $4(2)$ & $4(3.2)$ & 0 & \\
\hline Norwood procedure & $43(21.5)$ & 23 (18.6) & $20(26.3)$ & \\
\hline Heart transplant & $5(2.5)$ & $5(4)$ & 0 & \\
\hline Arterial switch operation & $25(12.5)$ & $17(13.7)$ & $8(10.5)$ & \\
\hline DORV repair & $3(1.5)$ & $2(1.6)$ & $1(1.3)$ & \\
\hline
\end{tabular}


TABLE 2. Continued

\begin{tabular}{lccc}
\hline & & Test cohort & \multicolumn{2}{c}{ Validation cohort } \\
Demographics, $\mathbf{n}=\mathbf{2 0 0}$ & Median (range) or $\mathbf{n}(\%)$ & $\mathbf{n}=\mathbf{1 2 4}(\%)$ & 0 \\
\hline Aortic arch repair & $5(2.5)$ & $5(4)$ & $3(4)$ \\
Interrupted aortic arch repair & $9(4.5)$ & $6(4.8)$ & $2(2.6)$ \\
Systemic to pulmonary shunt & $7(3.5)$ & $5(4)$ & $3(4)$ \\
Bidirectional Glenn & $11(5.5)$ & $8(6.5)$ & $4(5.3)$ \\
Hemi-Fontan & $5(2.5)$ & $1(0.8)$ & $4(5.3)$ \\
Valve repair/replacement & $7(3.5)$ & $3(2.4)$ & $3(4)$ \\
Other & $8(4)$ & $5(4)$ & \\
\hline
\end{tabular}

Data are expressed in either $\mathrm{n}(\%)$ (Fisher exact test) or median (range) (Wilcoxon rank some test). STAT, Society of Thoracic Surgeons-European Association for CardioThoracic Surgery; $N A$, not available; $M P V$, mean platelet volume (normal range $=6.5-9 \mathrm{fL}$ ); $N D$, not determined; $C P B$, cardiopulmonary bypass; $D H C A$, deep hypothermic circulatory arrest $\left(<22^{\circ} \mathrm{C}\right) ; r F V I I a$, recombinant activated factor VII; RBCs, red blood cells; $A S D$, atrial septal defect; VSD, ventricular septal defect; $A V C$, atrioventricular canal defect; TAPVC/R, total anomalous pulmonary venous connection/return; TOF, tetralogy of Fallot; DORV, double-outlet right ventricle. *Statistical analysis not performed for surgeon due to changes in staffing during the studies. Study populations were similar, although the validation cohort had more patients with a genetic syndrome and a greater percentage with cyanotic heart disease. The difference in baseline platelet count is statistically, but not clinically, significant.

76 neonates and infants in the prospective study, 15 $(19.5 \%)$ met the criteria for excessive CTO, and those had a 2.2-fold increase in risk of either RBC transfusion or re-exploration (95\% CI, 1.5-3.2, $P=.0012)$ compared with the 61 patients without excessive CTO. Four additional patients underwent re-exploration for cardiac tamponade for a total of 19 patients $(24.7 \%)$ who met criteria for postoperative bleeding. Risk ratio of RBC transfusion in patients with excessive bleeding was 2.4 (95\% CI, 1.6-3.6, $P=.0004)$. Variables associated with increased bleeding

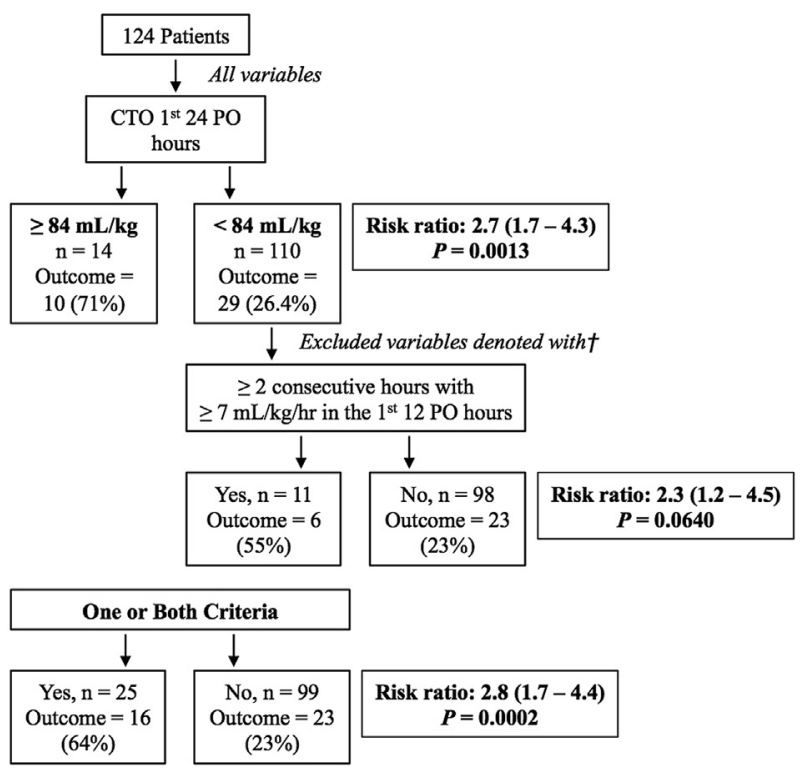

FIGURE 1. Summary of CART analysis of CTO as a predictor of the combined outcome of RBC transfusion and/or re-exploration for bleeding or tamponade in the first 24 postoperative hours in the test cohort. The primary node was an average CTO of $84 \mathrm{~mL} / \mathrm{kg}$ for the first 24 postoperative hours, and the secondary node was $\geq 2$ consecutive hours with $\geq 7 \mathrm{~mL} / \mathrm{kg} / \mathrm{h}$ in the first 12 postoperative hours. The Appendix E1 contains the full list of variables inputted into the model for both the first and second nodes. CTO, Chest tube output; $P O$, postoperative. risk were similar in both the test and validation cohorts (Tables 3 and 4).

\section{Outcomes in Test and Validation Cohorts}

The validation and test cohorts were combined to evaluate outcomes in patients with and without excessive bleeding. In addition to being more likely to receive a RBC transfusion in the first 24 hours, patients with excessive bleeding who underwent transfusion received a greater volume of $\mathrm{RBCs}$ $(25.6 \mathrm{~mL} / \mathrm{kg}$ vs $14.4 \mathrm{~mL} / \mathrm{kg}, P=.0002$ ) (Table 5). Excessive bleeding in the first 24 postoperative hours was also associated with increased number of transfusions of all blood components in the first postoperative week (Table 5).

In patients not undergoing a Norwood procedure, those with excessive bleeding had a longer length of hospital stay but a shorter time to in-hospital mortality than patients without bleeding (Figure 2). Among all patients, there was a trend toward increased risk of in-hospital mortality, 3.3\% in patients without bleeding and $10 \%$ in patients with bleeding; however, this was not statistically significant $(P=.1250$, Table 5). Patients with excessive bleeding had an increased risk of unplanned readmission $\leq 30$ days after discharge and thrombus within 14 days of surgery (Table 5).

\section{DISCUSSION}

The lack of a standardized, objective definition of excessive postoperative bleeding in neonates and infants undergoing cardiac surgery is a barrier to improving bleeding-related outcomes in these patients. The International Initiative for Haemostasis Management in Cardiac Surgery proposed and validated a universal definition of perioperative bleeding for adults undergoing cardiac surgery with $\mathrm{CPB} .{ }^{36}$ This scale uses a combination of CTO, transfusions and factor replacement received, and surgical re-exploration. For neonates and infants, the use of a similar rubric as the universal definition of perioperative bleeding may be valuable, but simply scaling CTO output linearly based on weight with respect to the adult data is not useful, eg, $>2000 \mathrm{~mL}$ in 12 hours is

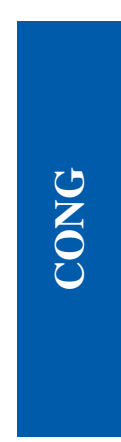


TABLE 3. Patient demographics and clinical characteristics of the retrospective (test) cohort, comparing patients with and without excessive bleeding

\begin{tabular}{|c|c|c|c|c|}
\hline Demographics $n=124$ & Patients without bleeding $(\mathrm{n}=93)$ & Patients with bleeding $(n=31)$ & Risk ratio & $P$ value \\
\hline Weight, kg & $4.2(2.4-8.7)$ & $3.1(2.2-7.5)$ & & $<.0001$ \\
\hline Age, d & $49(0-180)$ & $8(0-146)$ & & .0002 \\
\hline Sex, female & $39(42)$ & $17(54.8)$ & $1.3(0.8-2)$ & .2202 \\
\hline \multicolumn{5}{|l|}{ STAT score } \\
\hline 1 & $13(14.0)$ & $2(6.4)$ & & .0117 \\
\hline 2 & $20(21.5)$ & $2(6.4)$ & & \\
\hline 3 & $15(16.1)$ & $5(16.1)$ & & \\
\hline 4 & $31(33.3)$ & $8(25.8)$ & & \\
\hline 5 & $11(11.8)$ & $13(41.9)$ & & \\
\hline NA & $3(3.2)$ & $1(3.2)$ & & \\
\hline \multicolumn{5}{|l|}{ Preoperative labs } \\
\hline Hematocrit, \% & $41.2(24.2-55.7)$ & $41.8(26.2-52.9)$ & & .9733 \\
\hline Platelet count, $\times 10_{3} / \mu \mathrm{L}$ & $370(104-755)$ & $314(108-609)$ & & .1150 \\
\hline MPV, fL & $7.6(5.6-11.2)$ & $8.0(6-11.2)$ & & .0403 \\
\hline High MPV, $\geq 9.5 \mathrm{fL}$ & $7(7.5)$ & $7(23.3)$ & $3.4(1.3-8.7)$ & .0116 \\
\hline \multicolumn{5}{|l|}{ Surgeon } \\
\hline 1 & $27(29.0)$ & $4(12.9)$ & & .0758 \\
\hline 2 & $33(35.5)$ & $18(58.1)$ & & \\
\hline 3 & $33(35.5)$ & $9(29.0)$ & & \\
\hline Time on $\mathrm{CPB}$, min & $156(31-354)$ & $182(78-287)$ & & .0530 \\
\hline Minimum temperature, ${ }^{\circ} \mathrm{C}$ & $28.0(17.0-37.0)$ & $18(16.7-32)$ & & .0024 \\
\hline DHCA, yes & $28(30.1)$ & $19(61.3)$ & $2(1.3-3.1)$ & .0027 \\
\hline Intraoperative FVIIa & $5(5.4)$ & $6(19.4)$ & $3.6(1.1-11)$ & .0278 \\
\hline \multicolumn{5}{|l|}{ Prime } \\
\hline Whole blood & $61(65.6)$ & $11(35.5)$ & & .0068 \\
\hline RBCs + plasma & $31(33.3)$ & $19(61.3)$ & & \\
\hline Other & $1(1.1)$ & $1(3.2)$ & & \\
\hline Delayed chest closure & $37(39.8)$ & $26(83.9)$ & $2.1(1.5-2.9)$ & $<.0001$ \\
\hline \multicolumn{5}{|l|}{ Genetic syndrome } \\
\hline No & 73 (78.4) & $27(87.2)$ & & .2325 \\
\hline Trisomy 21 & $12(12.9)$ & $1(3.2)$ & & \\
\hline 22q11 deletion syndrome & $2(2.2)$ & $2(6.4)$ & & \\
\hline 16p duplication & 0 & 0 & & \\
\hline Other & $6(6.5)$ & $1(3.2)$ & & \\
\hline Single-ventricle physiology & $34(36.6)$ & $20(64.5)$ & $1.8(1.2-2.6)$ & .0113 \\
\hline Cyanotic heart disease (pre) & $61(65.6)$ & $27(87.1)$ & $1.3(1.1-1.7)$ & .0234 \\
\hline \multicolumn{5}{|l|}{ Procedure } \\
\hline ASD creation & 0 & $1(3.2)$ & & \\
\hline ASD or VSD repair & $11(11.8)$ & $2(6.5)$ & & \\
\hline AVC repair & $10(10.8)$ & 0 & & \\
\hline Truncus arteriosus repair & $2(2.2)$ & $1(3.2)$ & & \\
\hline TAPVC/R repair & $3(3.2)$ & $1(3.2)$ & & \\
\hline TOF repair & $8(3.2)$ & $1(3.2)$ & & \\
\hline Pulmonary atresia repair & $2(2.2)$ & $2(6.5)$ & & \\
\hline Norwood procedure & $11(11.8)$ & $12(38.7)$ & & \\
\hline Heart transplant & $4(4.3)$ & $1(3.2)$ & & \\
\hline Arterial switch operation & $12(12.9)$ & $5(16.3)$ & & \\
\hline DORV repair & $2(2.2)$ & 0 & & \\
\hline Aortic arch repair & $4(4.3)$ & $1(3.2)$ & & \\
\hline
\end{tabular}


TABLE 3. Continued

\begin{tabular}{|c|c|c|c|c|}
\hline Demographics $n=124$ & Patients without bleeding $(\mathrm{n}=93)$ & Patients with bleeding $(n=31)$ & Risk ratio & $P$ value \\
\hline Interrupted aortic arch repair & $4(4.3)$ & $2(6.5)$ & & \\
\hline Systemic to pulmonary shunt & $4(4.3)$ & $1(3.2)$ & & \\
\hline Bidirectional Glenn & $8(8.6)$ & 0 & & \\
\hline Hemi-Fontan & $1(1.1)$ & 0 & & \\
\hline Valve repair/replacement & $3(3.2)$ & 0 & & \\
\hline Other & $4(4.3)$ & $1(3.2)$ & & \\
\hline
\end{tabular}

Patients with and without bleeding had significant differences and in general patients with bleeding were younger, weighed less, and were more likely to have DHCA, delayed chest closure, and have cyanotic heart defects. Many of these variables are interdependent (eg, patients with single-ventricle physiology tend to be younger, require longer surgery with lower minimum body temperature, etc), and there was uneven distribution of neonates amongst the surgeons. STAT, Society of Thoracic Surgeons-European Association for Cardio-Thoracic Surgery; $N A$, not available; $M P V$, mean platelet volume (normal range $=6.5-9 \mathrm{fL}$ ); $C P B$, cardiopulmonary bypass; $D H C A$, deep hypothermic circulatory arrest $\left(<22^{\circ} \mathrm{C}\right) ; F V I I a$, recombinant activated factor VII; RBCs, red blood cells; $A S D$, atrial septal defect; VSD, ventricular septal defect; $A V C$, atrioventricular canal defect; TAPVC/R, total anomalous pulmonary venous connection/return; TOF, tetralogy of Fallot; DORV, double-outlet right ventricle.

an average of $2.2 \mathrm{~mL} / \mathrm{kg} / \mathrm{h}$ in a $75-\mathrm{kg}$ adult; in our study, 86 of the 200 infants ( $43 \%$ ), and in particular $57 \%$ of neonates, in both our test and validation cohorts would have had Grade 5 bleeding based on such scaling.

Despite the lack of consensus on a bleeding definition for neonates and infants, there are many reports of patients with excessive bleeding having inferior outcomes and longer lengths of hospital stay. ${ }^{3,4,13}$ These inferior outcomes may be directly associated with bleeding or secondary to the treatments required to manage bleeding such as transfusions or additional surgery. ${ }^{2}$ CTO is frequently used to determine postoperative bleeding. Advantages of using CTO include that it is easily quantifiable and begins at the set time of admission to CICU. In addition, it is routinely collected for clinical care and therefore should be readily available for use in both retrospective and prospective studies. However, determining the quantity of CTO that is excessive can be difficult, as evidenced by the various definitions in the literature. . $^{3,5,7,9-11,36}$

A challenge to defining bleeding is that there is no gold standard to which different levels of CTO can be compared. However, we propose that a definition of excessive CTO should be one that relates directly to risk of additional clinically relevant interventions. RBC transfusion and/or surgical re-exploration for bleeding, which expose patients to risks such as infection or anesthesia, were chosen because they are direct consequences for excessive CTO. ${ }^{2} \mathrm{Re}-$ exploration for bleeding or cardiac tamponade physiology without excessive CTO was included in our final definition of bleeding because patients may be taken for reexploration for a bleeding-related event without having increased CTO. This definition is as follows:

1. CTO $\geq 7 \mathrm{~mL} / \mathrm{kg} / \mathrm{h}$ for $\geq 2$ consecutive hours in the first 12 postoperative hours and/or;

2. $\geq 84 \mathrm{~mL} / \mathrm{kg}$ for the first 24 postoperative hours and/or; and

3. re-exploration for bleeding or tamponade in the first 24 postoperative hours.
Predictors of excessive bleeding based on this definition are similar to published ones: weight and minimum intraoperative temperature. ${ }^{1,11}$ Of interest and likely importance, we found that having a preoperative mean platelet volume greater than our institution's normal range (6.0-9.5 fL) was also associated with excessive bleeding in both the test and validation cohorts. Because platelet dysfunction is thought to be a primary contributor to perioperative bleeding, the relationships between platelet size, genetic syndromes such as 22q11 deletion syndrome, on-CPB platelet count and function, and postoperative outcomes such as bleeding and transfusion requirements is an area for further investigation. In the retrospective cohort, prime with whole blood was associated with reduced bleeding risk. Gruenwald and colleagues found that whole blood prime was associated with decreased CTO postoperatively, and our retrospective data support this finding whereas our prospective data do not. ${ }^{37}$

Our definition of bleeding is associated with worse outcomes, similar to other published reports., ${ }^{3,4}$ Among patients not undergoing a Norwood procedure, patients with postoperative bleeding had a longer length of stay and a shorter time to in-hospital death than patients without excessive bleeding. Patients with excessive bleeding who received more RBC, plasma, and platelet transfusions in the first postoperative week were more likely to develop a clinically significant thrombus in the first 2 postoperative weeks and were more likely to be readmitted within 30 days of primary discharge.

The decisions to transfuse RBCs or surgically re-explore a patient are difficult to standardize; however, the limited time course of this study and the relative limited number of clinicians involved in our clinical care team who typically jointly made these decisions reduces the impact of interprovider variability. CTO is a serosanguinous fluid, and depending on a patient's individual situation, may be more or less reflective of blood loss versus fluid loss, which is why we chose RBC transfusion rather than plasma 
TABLE 4. Patient demographics and clinical characteristics of the prospective (validation) cohort, comparing patients with and without excessive bleeding

\begin{tabular}{|c|c|c|c|c|}
\hline Demographics $n=76$ & Patients without bleeding $(n=57)$ & Patients with bleeding $(\mathrm{n}=19)$ & Risk ratio & $P$ value \\
\hline Weight, kg & $4.4(2.6-13.3)$ & $3.0(2.6-6.7)$ & & .0013 \\
\hline Age, d & $77(1-306)$ & $7(1-192)$ & & .0024 \\
\hline Sex, female & $29(50.9)$ & $12(63.1)$ & $1.2(0.8-2)$ & .4304 \\
\hline \multicolumn{5}{|l|}{ STAT score } \\
\hline 1 & $9(15.8)$ & 0 & & .0003 \\
\hline 2 & $18(31.6)$ & $2(10.5)$ & & \\
\hline 3 & $3(21)$ & 0 & & \\
\hline 4 & $7(12.3)$ & $8(42.1)$ & & \\
\hline 5 & $11(19.3)$ & $9(47.4)$ & & \\
\hline \multicolumn{5}{|l|}{ Preoperative labs } \\
\hline Hematocrit, \% & $40.7(31.4-60.5)$ & $43.2(32.2-58.4)$ & & .1991 \\
\hline Platelet count, $\times 10_{3} / \mu \mathrm{L}$ & $326(128-595)$ & $259(56-474)$ & & .0331 \\
\hline MPV, fL & $7.2(5.4-10.1)$ & $8.4(6.1-16.8)$ & & .0052 \\
\hline High MPV, $\geq 9.5$ fL & $1(1.8)$ & $7(36.8)$ & $21(2.7-159.9)$ & .0002 \\
\hline \multicolumn{5}{|l|}{ Surgeon* } \\
\hline 1 & $13(22.8)$ & $6(31.6)$ & & ND \\
\hline 2 & $5(8.8)$ & $6(31.6)$ & & \\
\hline 3 & $29(50.9)$ & $6(31.6)$ & & \\
\hline 4 & $10(17.5)$ & $1(5.2)$ & & \\
\hline Time on $\mathrm{CPB}$, min & $149(40-373)$ & $202(88-696)$ & & .0414 \\
\hline Minimum temperature, ${ }^{\circ} \mathrm{C}$ & $30.3(14.1-35)$ & $17.3(15.1-33.6)$ & & .0003 \\
\hline DHCA, yes & $12(21.1)$ & $14(73.7)$ & $3.5(1.9-6.2)$ & $<.0001$ \\
\hline Intraoperative FVIIa & $2(3.5)$ & $1(5.3)$ & $1.5(0.1-15.7)$ & 1.0 \\
\hline \multicolumn{5}{|l|}{ Prime } \\
\hline Whole blood & $20(35)$ & $7(36.8)$ & & 1.0000 \\
\hline RBCs + plasma & $36(63.2)$ & $12(63.2)$ & & \\
\hline Other & $1(1.8)$ & 0 & & \\
\hline Delayed chest closure & $17(29.8)$ & $15(79)$ & $2.6(1.6-4.2)$ & .0003 \\
\hline \multicolumn{5}{|l|}{ Genetic syndrome } \\
\hline No & $38(66.7)$ & $12(63.2)$ & & .6051 \\
\hline Trisomy 21 & $8(14)$ & $2(10.5)$ & & \\
\hline $22 q 11$ deletion syndrome & $3(5.3)$ & $3(15.8)$ & & \\
\hline 16p duplication & $3(5.3)$ & 0 & & \\
\hline Other & $5(8.7)$ & $2(10.5)$ & & \\
\hline Single-ventricle physiology & $18(31.6)$ & $14(73.7)$ & $2.3(1.4-3.8)$ & .0025 \\
\hline Cyanotic heart disease (pre) & $45(79)$ & $19(100)$ & $1.3(1.1-1.7)$ & .0307 \\
\hline \multicolumn{5}{|l|}{ Procedure } \\
\hline ASD creation & $1(1.8)$ & 0 & & \\
\hline ASD or VSD repair & $7(12.3)$ & 0 & & \\
\hline AVC repair & $5(8.8)$ & 0 & & \\
\hline Truncus arteriosus repair & 0 & $1(5.3)$ & & \\
\hline TAPVC/R repair & $1(1.8)$ & $1(5.3)$ & & \\
\hline TOF repair & $9(15.8)$ & $3(15.8)$ & & \\
\hline Pulmonary atresia repair & 0 & 0 & & \\
\hline Norwood procedure & $11(19.3)$ & $9(47.4)$ & & \\
\hline Heart transplant & 0 & 0 & & \\
\hline Arterial switch operation & $8(14)$ & 0 & & \\
\hline DORV repair & 0 & $1(5.3)$ & & \\
\hline Aortic arch repair & 0 & 0 & & \\
\hline
\end{tabular}


TABLE 4. Continued

\begin{tabular}{|c|c|c|c|c|}
\hline Demographics $n=76$ & Patients without bleeding $(n=57)$ & Patients with bleeding $(\mathrm{n}=19)$ & Risk ratio & $P$ value \\
\hline Interrupted aortic arch repair & $1(1.8)$ & $2(10.6)$ & & \\
\hline Systemic to pulmonary shunt & $1(1.8)$ & $1(5.3)$ & & \\
\hline Bidirectional Glenn & $3(5.3)$ & 0 & & \\
\hline Hemi-Fontan & $3(5.3)$ & $1(5.3)$ & & \\
\hline Valve repair/replacement & $4(7)$ & 0 & & \\
\hline Other & $3(5.3)$ & 0 & & \\
\hline
\end{tabular}

Differences between patients with and without excessive postoperative bleeding are similar in the validation cohort as the test cohort. STAT, Society of Thoracic Surgeons-European Association for Cardio-Thoracic Surgery; $M P V$, mean platelet volume (normal range $=6.5-9 \mathrm{fL}$ ); $N D$, not determined; $C P B$, cardiopulmonary bypass; $D H C A$, deep hypothermic circulatory arrest $\left(<22^{\circ} \mathrm{C}\right)$; FVIIa, recombinant activated factor VII; RBCs, red blood cells; $A S D$, atrial septal defect; VSD, ventricular septal defect; $A V C$, atrioventricular canal defect; TAPVC/R, total anomalous pulmonary venous connection/return; TOF, tetralogy of Fallot; $D O R V$, double-outlet right ventricle. *Statistical analysis not performed for surgeon due to changes in staffing during the studies.

transfusion as an indicator of blood loss. In addition, CTO in the first few hours after surgery is more commonly reflective of blood loss.

The proposed definition was developed and validated only in neonates and infants, collectively representing the majority of greater risk patients with a greater percentage of postoperative complications. For this group, our definition may be superior to previously published definitions that were based on cohorts with broader age ranges (Video 1). However, the methodology used to determine the amount and duration of CTO associated with outcomes of interest could theoretically be applied to older pediatric patients. The purpose of our standardized definition of postoperative excessive bleeding is for use as a common data element in both single- and multi-institutional trials, as well as research databases and to facilitate the development of predictive models to identify at-risk patients as well as optimize interventions to prevent and treat postoperative bleeding.

\section{Limitations}

Because the management of bleeding and transfusion practice varies widely across pediatric cardiac centers, our single-institution study and the resultant definition of bleeding would likely lead to variations in incidence of bleeding and other secondary outcomes (length of stay, duration of mechanical ventilation, mortality, etc); external validation is needed verify the utility of this definition. This concern does not negate the value of this definition based on clinically relevant and measurable criteria. We acknowledge the somewhat-arbitrary nature of outcome criteria on which to base the CTO analysis (eg, transfusion and/or

TABLE 5. Postoperative transfusions and complications in patients with and without excessive postoperative bleeding in the retrospective cohort

\begin{tabular}{|c|c|c|c|c|c|}
\hline Outcome & $\begin{array}{l}\text { All subjects } \\
\mathbf{n}=\mathbf{2 0 0}(\%)\end{array}$ & $\begin{array}{c}\text { Patients without bleeding } \\
\mathbf{n}=\mathbf{1 5 0}(\%)\end{array}$ & $\begin{array}{c}\text { Patients with bleeding } \\
\mathbf{n}=\mathbf{5 0}(\%)\end{array}$ & $\begin{array}{r}\text { Risk ratio } \\
(95 \% \text { CI })\end{array}$ & $P$ value \\
\hline \multicolumn{6}{|c|}{$\mathrm{RBCs} / \mathrm{WB}$ transfused in the first $24 \mathrm{~h}$ postoperatively } \\
\hline Number & $63(31.5)$ & $32(20.7)$ & $31(64)$ & $3.1(2.1-4.6)$ & $<.0001$ \\
\hline Volume, $\mathrm{mL} / \mathrm{kg} *$ & $16(1.2-227.7)$ & $14.4(1.2-30.7)$ & $25.6(6.7-227.7)$ & & .0002 \\
\hline \multicolumn{6}{|c|}{ Transfused in the first $7 \mathrm{~d}$ postoperatively, $\mathrm{n}(\%)$} \\
\hline $\mathrm{RBCs} / \mathrm{WB}$ & $93(46.5)$ & $53(35.5)$ & $40(80)$ & $2.3(1.7-3)$ & $<.0001$ \\
\hline Plasma & $65(32.5)$ & 25 (16.7) & $40(80)$ & $2.3(1.7-3)$ & $<.0001$ \\
\hline Platelets & $22(11)$ & $11(7.3)$ & $11(22)$ & $3.0(1.3-6.5)$ & .0077 \\
\hline \multicolumn{6}{|c|}{ Transfused in the first $7 \mathrm{~d}, \mathrm{~mL} / \mathrm{kg}^{*}$} \\
\hline RBCs/WB & $16.1(1.2-581)$ & $14.9(1.2-128.7)$ & $32.4(9.8-581)$ & & $<.0001$ \\
\hline Plasma & $26.2(4.5-479)$ & $20.8(8.9-130.9)$ & $37.1(4.5-479)$ & & .0217 \\
\hline Platelets & $19.3(1.8-138)$ & $15.7(1.8-44.1)$ & $37.5(2.4-138)$ & & .1300 \\
\hline Donor exposures & $5(0-40)$ & $4(0-22)$ & $8.5(1-40)$ & & .0002 \\
\hline Infection & $24(12)$ & $19(12.7)$ & $5(10)$ & $0.8(0.3-2.1)$ & .8026 \\
\hline Stroke $\dagger$ & $5(2.5)$ & $4(2.8)$ & $1(2)$ & $0.8(0.1-6.7)$ & 1.0 \\
\hline Thrombotic event & $18(9)$ & $9(6)$ & $9(18)$ & $3.0(1.2-7.1)$ & .0194 \\
\hline Unplanned readmission $\leq 30 \mathrm{~d} \ddagger$ & $29(14.5)$ & $15(10.3)$ & $14(31.1)$ & $3.0(1.5-5.8)$ & .0016 \\
\hline In-hospital mortality & $10(5)$ & $5(3.3)$ & $5(10)$ & $3.0(0.9-10)$ & .1250 \\
\hline
\end{tabular}

$C I$, Confidence interval; $R B C$, red blood cell; $W B$, whole blood. *Analysis includes only transfused patients. $\dagger$ Missing data for 9 patients ( 6 without and 3 with excessive bleeding). $\ddagger$ Excludes the 10 patients who died before discharge. 

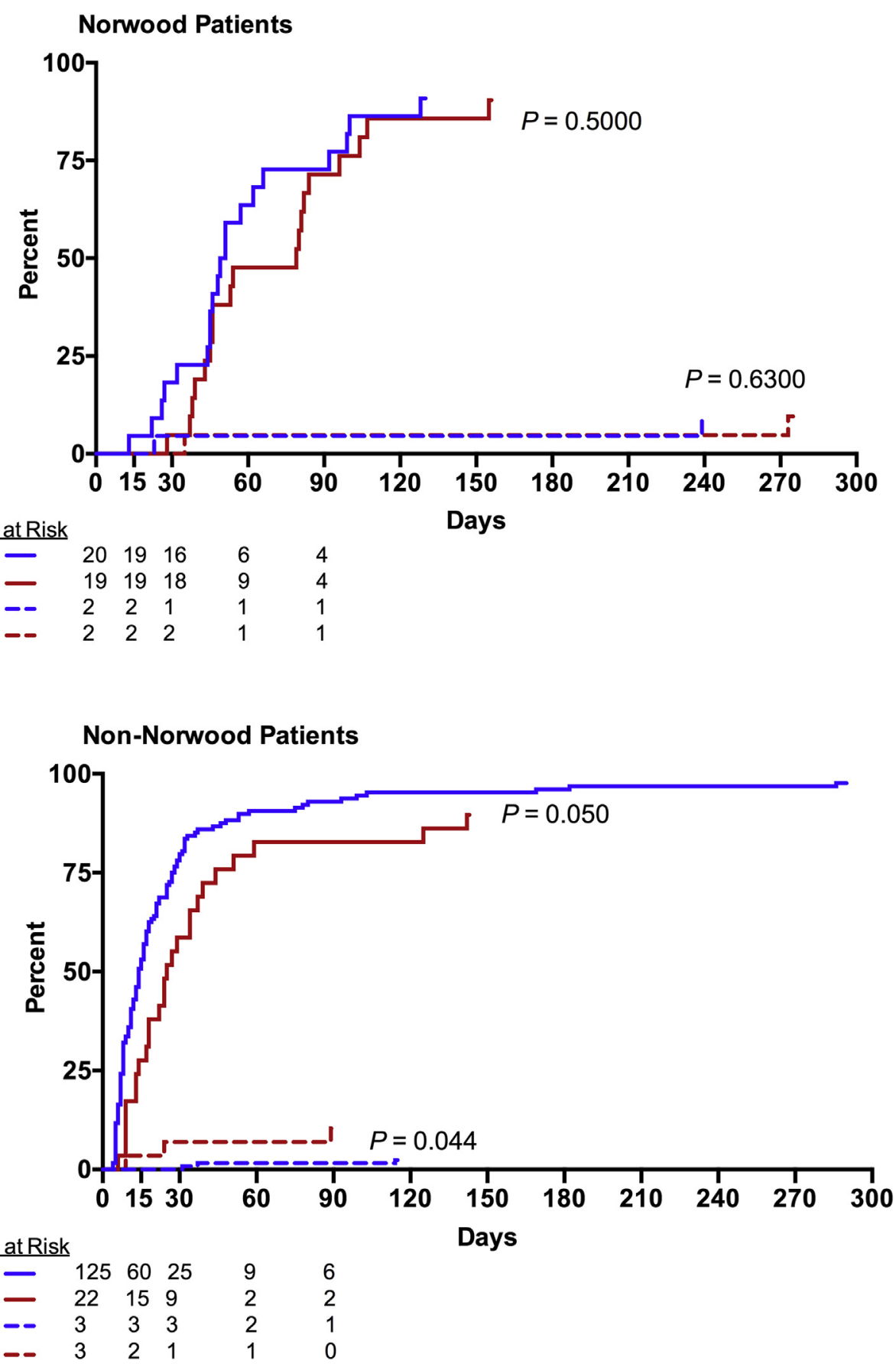

FIGURE 2. Time to discharge or in-hospital death in patients with (red line) and without (blue line) excessive bleeding undergoing either a Norwood procedure (A) or another surgery (B). Patients were divided based on operation because patients undergoing a Norwood procedure were likely to remain hospitalized until the second stage surgery, whereas other patients were not. There was no difference in LOS or time to in-hospital mortality based on bleeding in patients undergoing a Norwood procedure, whereas patients with excessive bleeding who did not undergo a Norwood procedure had a significantly longer LOS (median $=25$ days vs 14 days, $P=.05)$ and a shorter time to mortality $(P=.044)$ than patients without bleeding. Please see Table E1 for the $95 \%$ confidence interval on days $15,30,60$, and 90 . NB, No bleeding; $D C$, discharged; $B$, bleeding; $I H D$, in-hospital death.

re-exploration). However, we suggest that most clinicians would agree that these are clinically relevant outcomes directly related to bleeding. One may question the use of re-exploration for cardiac tamponade physiology, as such an event could occur in the absence of large volume blood loss (eg, focal tamponade from excessive clotting). However, in our experience, this is an exception. Because re-exploration relating to a bleeding process indeed seems 


\section{Validation of a definition of excessive postoperative bleeding in infants undergoing cardiac surgery with cardiopulmonary bypass}

\author{
Rachel S. Bercovitz, MD MS \\ Associate Medical Director, BloodCenter of Wisconsin \\ Assistant Professor of Pediatrics and Pathology, \\ Medical College of Wisconsin
}

VIDEO 1. Dr Rachel Bercovitz summarizes the study's objectives and findings. Video available at: http://www.jtcvsonline.org/article/S00225223(17)32846-5/fulltext.

relevant, we felt it was necessary to include it in the definition.

\section{CONCLUSIONS}

CTO is commonly used to define postoperative bleeding, but published definitions vary widely and may not correlate with poor outcomes. The definition of excessive bleeding proposed in this manuscript is associated with relevant outcomes such as increased transfusions and re-exploration, and preliminary investigation suggests that excessive bleeding is associated with worse postoperative outcomes such as longer length of stay or increased risk of unplanned readmission. A standard definition, like the one proposed, will improve strategies to study, diagnose, prevent, and treat excessive postoperative bleeding in neonates and infants undergoing cardiac surgery with $\mathrm{CPB}$.

\section{Conflict of Interest Statement}

Authors have nothing to disclose with regard to commercial support.

\section{References}

1. Szekely A, Cserep Z, Sapi E, Breuer T, Nagy CA, Vargha P, et al. Risks and predictors of blood transfusion in pediatric patients undergoing open heart operations. Ann Thorac Surg. 2009;87:187-97.

2. Vivacqua A, Koch CG, Yousuf AM, Nowicki ER, Houghtaling PL, Blackstone EH, et al. Morbidity of bleeding after cardiac surgery: is it blood transfusion, reoperation for bleeding, or both? Ann Thorac Surg. 2011;91:1780-90.

3. Guzzetta NA, Allen NN, Wilson EC, Foster GS, Ehrlich AC, Miller BE. Excessive postoperative bleeding and outcomes in neonates undergoing cardiopulmonary bypass. Anesth Analg. 2015;120:405-10.

4. Wolf MJ, Maher KO, Kanter KR, Kogon BE, Guzzetta NA, Mahle WT. Early postoperative bleeding is independently associated with increased surgical mortality in infants after cardiopulmonary bypass. J Thorac Cardiovasc Surg. 2014; 148:631-6.e1.

5. Agarwal HS, Barrett SS, Barry K, Xu M, Saville BR, Donahue BS, et al. Association of blood products administration during cardiopulmonary bypass and excessive post-operative bleeding in pediatric cardiac surgery. Pediatr Cardiol. 2015;36:459-67.

6. Brenner MK, Clarke S, Mahnke DK, Simpson P, Bercovitz RS, TomitaMitchell A, et al. Effect of 22q11.2 deletion on bleeding and transfusion utilization in children with congenital heart disease undergoing cardiac surgery. Pediatr Res. 2016;79:318-24.
7. Hoda M, Haque A, Aijaz F, Akhtar MI, Rehmat A, Amanullah M, et al. On-table extubation after open heart surgery in children: an experience from a tertiary care hospital in a developing country. Congenit Heart Dis. 2016;11:58-62.

8. Kylasam S, Mos K, Fijtin S, Webster B, Chard R, Egan J. Recombinant activated factor VII following pediatric cardiac surgery. J Intensive Care Med. 2009;24: 116-21.

9. Moganasundram S, Hunt BJ, Sykes K, Holton F, Parmar K, Durward A, et al. The relationship among thromboelastography, hemostatic variables, and bleeding af ter cardiopulmonary bypass surgery in children. Anesth Analg. 2010;110: 995-1002.

10. Niebler RA, Gill JC, Brabant CP, Mitchell ME, Nugent M, Simpson P, et al Thromboelastography in the assessment of bleeding following surgery for congenital heart disease. World J Pediatr Congenit Heart Surg. 2012:3:433-8.

11. Williams GD, Bratton SL, Ramamoorthy C. Factors associated with blood loss and blood product transfusions: a multivariate analysis in children after openheart surgery. Anesth Analg. 1999;89:57-64.

12. Niles SD, Burkhart HM, Duffey DA, Buhrman K, Burzynski J, Holt DW. Use of recombinant factor VIIa (NovoSeven) in pediatric cardiac surgery. J Extra Cor por Technol. 2008;40:241-8.

13. Pagowska-Klimek I, Pychynska-Pokorska M, Krajewski W, Moll JJ. Predictors of long intensive care unit stay following cardiac surgery in children. Eur J Cardiothorac Surg. 2011;40:179-84.

14. Pekelharing J, Furck A, Banya W, Macrae D, Davidson SJ. Comparison between thromboelastography and conventional coagulation tests after cardiopulmonary bypass surgery in the paediatric intensive care unit. Int J Lab Hematol. 2014; 36:465-71.

15. Pychynska-Pokorska M, Moll JJ, Krajewski W, Jarosik P. The use of recombinant coagulation factor VIIa in uncontrolled postoperative bleeding in children undergoing cardiac surgery with cardiopulmonary bypass. Pediatr Crit Care Med 2004;5:246-50.

16. Razon Y, Erez E, Vidne B, Birk E, Katz J, Tamari H, et al. Recombinant factor VIIa (NovoSeven) as a hemostatic agent after surgery for congenital heart disease. Paediatr Anaesth. 2005;15:235-40.

17. Singh SP, Chauhan S, Choudhary M, Vasdev S, Talwar S. Recombinant activated factor VII for hemorrhage after pediatric cardiac surgery. Asian Cardiovasc Thorac Ann. 2012;20:19-23.

18. Timpa JG, O'Meara LC, Goldberg KG, Phillips JP, Crawford JH, Jackson KW et al. Implementation of a multidisciplinary bleeding and transfusion protocol significantly decreases perioperative blood product utilization and improves some bleeding outcomes. J Extra Corpor Technol. 2016;48:11-8.

19. Tirosh-Wagner T, Strauss T, Rubinshtein M, Tamarin I, Mishaly D, Paret G, et al Point of care testing in children undergoing cardiopulmonary bypass. Pediatr Blood Cancer. 2011;56:794-8.

20. Savan V, Willems A, Faraoni D, Van der Linden P. Multivariate model for predicting postoperative blood loss in children undergoing cardiac surgery: a preliminary study. Br J Anaesth. 2014;112:708-14.

21. Benneyworth BD, Mastropietro CW, Graham EM, Klugman D, Costello JM, Zhang W, et al. Variation in extubation failure rates after neonatal congenital heart surgery across Pediatric Cardiac Critical Care Consortium hospitals. J Thorac Cardiovasc Surg. 2017;153:1519-26.

22. Tobias JD, Simsic JM, Weinstein S, Schechter W, Kartha V, Michler R. Recombinant factor VIIa to control excessive bleeding following surgery for congenital heart disease in pediatric patients. J Intensive Care Med. 2004; 19:270-3.

23. Nakayama Y, Nakajima Y, Tanaka KA, Sessler DI, Maeda S, Iida J, et al. Thromboelastometry-guided intraoperative haemostatic management reduces bleeding and red cell transfusion after paediatric cardiac surgery. Br J Anaesth. 2015;114:91-102.

24. Eisses MJ, Chandler WL. Cardiopulmonary bypass parameters and hemostatic response to cardiopulmonary bypass in infants versus children. J Cardiothorac Vasc Anesth. 2008;22:53-9.

25. Petricevic M, Konosic S, Biocina B, Dirkmann D, White A, Mihaljevic MZ, et al Bleeding risk assessment in patients undergoing elective cardiac surgery using $\operatorname{ROTEM}((\mathrm{R}))$ platelet and Multiplate((R)) impedance aggregometry. Anaesthesia. 2016;71:636-47.

26. Krishnamurthy G, Ratner V, Bacha E. Neonatal cardiac care, a perspective. Semin Thorac Cardiovasc Surg Pediatr Card Surg Annu. 2013;16:21-31.

27. Andrew M, Paes B, Milner R, Johnston M, Mitchell L, Tollefsen DM, et al. Development of the human coagulation system in the full-term infant. Blood. 1987;70:165-72.

28. Hornykewycz S, Odegard KC, Castro RA, Zurakowski D, Pigula F, DiNardo JA. Hemostatic consequences of a non-fresh or reconstituted whole blood small vol- 
ume cardiopulmonary bypass prime in neonates and infants. Paediatr Anaesth. 2009; 19:854-61.

29. Steinberg D, Colla P. CART: Tree-Structured Non-parametric Data Analysis. San Diego, CA: Salford Systems; 1995.

30. Lewis RJ. An introduction to classification and regression tree (CART) analysis. Presented at: Annual Meeting of the Society for Academic Emergency Medicine, San Francisco, CA, Citeseer; 2000:1-14.

31. Brock GN, Barnes C, Ramirez JA, Myers J. How to handle mortality when investigating length of hospital stay and time to clinical stability. BMC Med Res Methodol. 2011;11:144.

32. Faraoni D, Willems A, Romlin BS, Belisle S, Van der Linden P. Development of a specific algorithm to guide haemostatic therapy in children undergoing cardiac surgery: a single-centre retrospective study. Eur J Anaesthesiol. 2015;32:320-9.

33. Guay J, Rivard GE. Mediastinal bleeding after cardiopulmonary bypass in pediatric patients. Ann Thorac Surg. 1996;62:1955-60.

34. Oliver WC. Hemostasis, coagulation, and transfusion in the pediatric cardiac patient. In: Lake CL, Booker PD, eds. Pediatric Cardiac Anesthesia. 4th ed. Philadelphia, PA: Lippincott Williams \& Wilkins; 2005:304-13.
35. DiNardo JA. Physiology and techniques of extracorporeal circulation in the pediatric patient. In: Lake CL, Booker PD, eds. Pediatric Cardiac Anesthesia. 4th ed. Philadelphia, PA: Lippincott Williams \& Wilkins; 2005: 228-52.

36. Dyke C, Aronson S, Dietrich W, Hofmann A, Karkouti K, Levi M, et al. Universal definition of perioperative bleeding in adult cardiac surgery. J Thorac Cardiovasc Surg. 2014;147:1458-63.e1.

37. Gruenwald CE, McCrindle BW, Crawford-Lean L, Holtby H, Parshuram C, Massicotte $\mathrm{P}$, et al. Reconstituted fresh whole blood improves clinical outcomes compared with stored component blood therapy for neonates undergoing cardiopulmonary bypass for cardiac surgery: a randomized controlled trial. J Thorac Cardiovasc Surg. 2008;136:1442-9.

Key Words: congenital heart disease, blood loss, postoperative, cardiopulmonary bypass, infants, cardiac surgery, blood transfusions 


\section{APPENDIX E1}

Variables inputted into the CART model:

CTO as a continuous variable:

Average for the first $2,4,6, * 12, *$ and $24 *$ hours $\dagger$

CTO in hours 1-2, 3-6, ${ }^{*}$ and hours $7-12 *$ postoperatively

Published definitions:

Agarwal and colleagues ${ }^{5}$

Faraoni and colleagues ${ }^{32}$

Guay and Rivard ${ }^{33}$

Guzzetta and colleagues ${ }^{3}$

Hoda and colleagues ${ }^{7}, *$

Moganasundram and colleagues ${ }^{9}$

Niebler and colleagus ${ }^{10}$

Niles and colleagues ${ }^{12}$

Pychynska-Pokorska and colleagues ${ }^{15}$

Pekelharing and colleagues ${ }^{14}$

Razon and colleagues ${ }^{16}$

Timpa and colleagues ${ }^{18}$

Tirosh-Wagner and colleagues ${ }^{19}$

Tobias and colleagues ${ }^{22}$
Williams and colleagues ${ }^{11}$

Wolf and colleagues ${ }^{4}$

CTO in a single hour $(\mathrm{mL} / \mathrm{kg} / \mathrm{h})$ in the first 6 and 12 hours: $\geq 10, \geq 15, \geq 20$

CTO in $\geq 2$ nonconsecutive hours $(\mathrm{mL} / \mathrm{kg} / \mathrm{h})$ in the first 6 and 12 hours: $\geq 10, \geq 15, \geq 20$

CTO per hour for consecutive or no-consecutive hours during different postoperative time periods (all permutations listed below were included):

\begin{tabular}{lcc}
\hline CTO, $\mathbf{~} \mathbf{L} / \mathbf{k g} / \mathbf{h}$ & Number of hours & $\begin{array}{c}\text { Time period (from time of } \\
\text { CICU admission) }\end{array}$ \\
\hline 3 & 2 & 6 \\
4 & 3 & 12 \\
\hline 5 & 4 & 24 \\
\hline 6 & 5 & \\
\hline 7 & 6 & \\
\hline 8 & & \\
\hline 9 & & \\
\hline CTO, Chest tube output; $C I C U$, cardiac intensive care unit.
\end{tabular}

\footnotetext{
* Variables not included in the second node.

${ }^{\dagger}$ All hour values refer to hour 0 being time of admission to the CICU. As anticipated, very high values (eg, $\geq 20 \mathrm{~mL} / \mathrm{kg}$ for $\geq 2$ hours in the first 6 hours) had excellent specificity but poor sensitivity. Relatively low values (eg, $\geq 2 \mathrm{~mL} / \mathrm{kg} / \mathrm{h}$ average for the first 24 hours) had good sensitivity but poor specificity.
} 


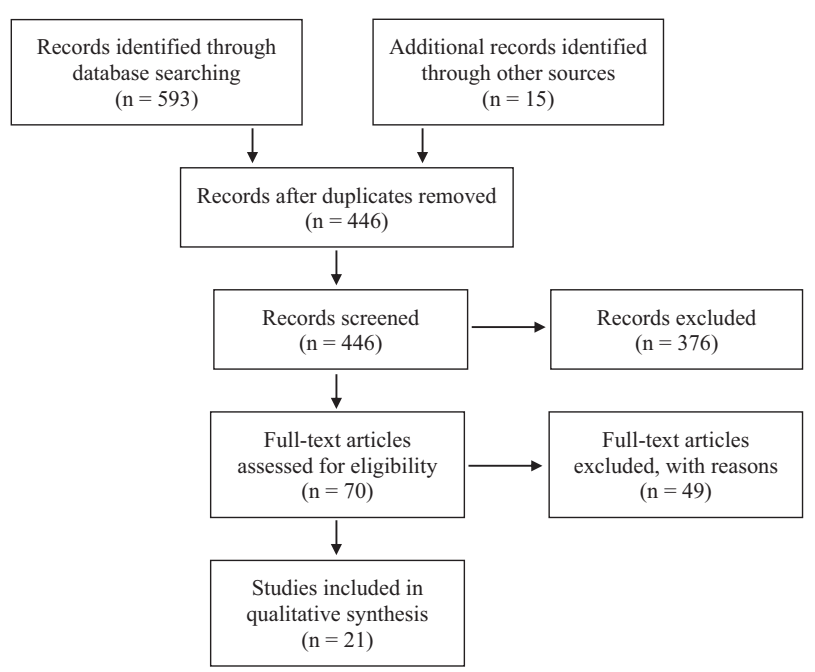

FIGURE E1. Preferred Reporting Items for Systematic Reviews and Meta-Analyses flow diagram. Search terms in PubMed were ((()(((bleed*) OR "excessive bleeding”) OR "bled excessively") OR HEMORRHAGE)) AND surgery) AND card*) AND "cardiopulmonary bypass." Additional sources were found by looking through references of full-text articles that were assessed for eligibility. Search updated February 17, 2017.

TABLE E1. Estimated probability with confidence intervals time-to-event analyses in Figure $2, A$ and $B$

\begin{tabular}{|c|c|c|c|c|}
\hline & Day 15 & Day 30 & Day 60 & Day 90 \\
\hline \multicolumn{5}{|l|}{ Norwood Patients } \\
\hline \multicolumn{5}{|c|}{ Hospital discharge $(P=.5000)$} \\
\hline Bleeding & $0(0-10.3)$ & $4.8(0-18.2)$ & $47.6(34.4-60.8)$ & $71.4(59.6-83.2)$ \\
\hline No bleeding & $4.5(0-12.6)$ & $18.2(10.8-25.5)$ & $63.6(58.1-69.2)$ & $72.7(67.8-77.6)$ \\
\hline \multicolumn{5}{|c|}{ In-hospital death $(P=.6300)$} \\
\hline Bleeding & $0(0-3.9)$ & $0(0-5.5)$ & $4.8(0-11.4)$ & $4.8(0-12.5)$ \\
\hline No bleeding & $0(0-0)$ & $4.5(3.2-5.9)$ & $4.5(2.3-6.8)$ & $4.5(2.3-6.8)$ \\
\hline \multicolumn{5}{|c|}{ Non-Norwood Patients } \\
\hline \multicolumn{5}{|c|}{ Hospital discharge $(P=.0500)$} \\
\hline Bleeding & $27.6(17.3-37.9)$ & $58.6(45.2-72.1)$ & $82.8(69.6-95.9)$ & $82.8(70.9-94.6)$ \\
\hline No bleeding & $53.1(45.1-61.1)$ & $79.7(72.3-87)$ & $90.6(85.1-96.1)$ & $93(88.1-97.9)$ \\
\hline \multicolumn{5}{|c|}{ In-hospital death $(P=.0440)$} \\
\hline Bleeding & $3.4(0-7.4)$ & $6.9(1.4-12.4)$ & $6.9(0.2-13.6)$ & $10.3(2.6-18.1)$ \\
\hline No bleeding & $0(0-0)$ & $0(0-1.3)$ & $1.6(0-3.8)$ & $1.6(0-3.8)$ \\
\hline
\end{tabular}

